\title{
DESIGN OF PERFORMANCE EVALUATION TOOLS FOR DRAINAGE OF ROADS SYSTEM IN DEVELOPING COUNTRY (CASE STUDY: DRAINAGE SYSTEM FOR CITY ROADS IN PADANG INDONESIA)
}

\author{
Insannul Kamil ${ }^{*}$ \\ Faculty of Geoinformation and Real Estate \\ Universiti Teknologi Malaysia \\ E-mail: sankamil@yahoo.com \\ Buang Alias \\ Faculty of Geoinformation and Real Estate \\ Universiti Teknologi Malaysia \\ E-mail: buang@utm.my \\ Abdul Hakim Mohammed \\ Faculty of Geoinformation and Real Estate \\ Universiti Teknologi Malaysia \\ E-mail: abdhakim@utm.my \\ Nilda Tri Putri \\ Industrial Engineering Department \\ Andalas University, Padang, Indonesia \\ E-mail: nilda@ft.unand.ac.id \\ Cresti Kalani \\ Industrial Engineering Department \\ Andalas University, Padang, Indonesia \\ E-mail: crestikalani@gmail.com
}

\begin{abstract}
Roads are the ground transport infrastructure which includes all parts of the road, including complementary buildings and equipment intended for traffic. Padang city as the capital of West Sumatra province requires road transport system to meet the needs of service to the needs of the community in various fields. However, after conducting surveys and interviews with the Public Works Department City of Padang, most roads in the city of Padang were damaged. One of the main causes of damage to the road is a puddle of water that had flooded the road. During this unprecedented performance evaluation system that delivers good performance standards for roads drainage in Padang City, Indonesia. The absence of performance standards has resulted roads drainage performance in Padang for the worse. As a result, roads drainage does not function well in a puddle of water flow and if it is allowed then the road will be damaged and cause greater harm in the future.

The design of the performance evaluation system is done by using Key Performance Indicators (KPI) are adopted from other countries. KPI is tailored to the conditions of the roads drainage in the city of Padang. KPI adjustments will be done through surveys and in-depth interviews to consider the opinions of experts in the field of roads drainage. KPIs will be adjusted weighted by AHP (Analytical Hierarchy Process) to determine the importance of KPI. Giving weights through pair wise comparisons by experts who have the knowledge and understanding of the model designed. Further assessment was conducted to evaluate the performance of the roads drainage.

The results of the performance evaluation are a roads drainage performance of Padang with the performance level 3.455 out of 10. This performance level is at the level of bad. The low achievement
\end{abstract}

\footnotetext{
* Corresponding author
} 
drainage refers to the condition of the actual performance of the roads drainage Padang. Poor performance is caused by many things such as the physical condition of the damaged drainage, lack of public awareness, the slow response of the government in dealing with drainage and so forth. Roads drainage actual performance of Padang in particular seen from the performance level of each KPI, the KPI frequency of maintenance (poor achievement levels), KPI maintenance costs (poor achievement levels), KPI type drainage (poor achievement levels), KPI drainage (poor achievement levels), operating KPI drainage (poor achievement levels), KPI level of the government's response to the problems of drainage (medium level of achievement), KPI awareness (poor achievement levels), KPI status of waste (poor achievement levels), and regional sustainability KPI drainage flow (moderate level of achievement). This research provides useful recommendations for improving the performance of the roads drainage Padang.

Keywords: design of performance evaluation systems, key performance indicators, Analytical Hierarchy Process (AHP), roads drainage performance evaluation.

\section{Introduction}

Roads are the ground transport infrastructure which includes all parts of the road, including buildings and equipment complement that cater for the traffic that is on the surface of the soil, subsurface soil and / or water, except for the railroad, street and road lorries cable (Law Republic of. 38 in 2004). Padang city as the capital of West Sumatra province requires road transport system is good and adequate to meet the needs of the service to the needs of the community in the areas of government, commerce, education, healthcare, industrial economics, and more. However, after surveying the field and a brief interview with the Public Works Department City of Padang, the condition of roads in Padang were damaged by different types and levels of damage are the most severe damage in Alai Market Street and Roads Bypass - Gulf Bayur. Based on observations made the kind of damage that occurred on the road is bumpy, pitted and cracked.

Damage that occurred on the road can disrupt and endanger the safety of all road users. Based on data from the Roadss Department of Public Works (Public Works) of Padang and interviews with public works employees Padang, the main cause of road damage in Padang is a puddle of water that had flooded the road. Puddles lead to decreased quality of roads and if allowed to persist will lead the way into the cracks and holes (Nurhudayah, 2009).

Stagnant water cannot be addressed because the drainage is not working properly drain water from the road. Roads drainage only designed and built without regard to good or bad performance. Many found that the roads drainage has been constructed does not work properly (not able to drain the stagnant water in the road because of the condition of the existing drainage damaged, clogged, not well maintained, high sediment and others) (Putri et al. 2012).

Based on interviews with Head of Natural Resources Department of Public Works Padang, there has never been a performance assessment system designed to measure and assess the performance of the roads drainage Padang. The lack of drainage system performance resulted roads drainage performance of the roads in the city of Padang to be bad and not as expected. As a result, roads drainage does not function well in draining standing water from the road. If it is allowed then the roads will be damaged and need a big cost in the planning, construction and maintenance of roadss. Therefore, it is necessary designed a performance assessment system to establish clear performance standards for roads drainage

\section{Methods}

Steps being taken in this research study are a preliminary study, data collection, identification of experts, determining the KPIs using the Delphi method, weighting by the AHP, and roads drainage performance assessment. 


\section{Process}

\subsection{Determination of Key Performance Indicators}

Forty-nine KPI derived from previous researchers. Experts' opinions are used to filter the KPI if could have been used for roads drainage performance assessment in the city of Padang. 27 obtained from the phase determination KPI to be used with the first round of the Delphi method. Further the second round of the Delphi method. The second round of the Delphi method to ask the experts add parameters, performance measures, and KPIs regrouping. The consensus of the experts is obtained in the third round of the Delphi method. The consensus of the experts is 9 and their KPI, KPI categories, parameters and performance measures can be seen in Table 1 .

Table 1. Expert Consensus

\begin{tabular}{|c|c|c|c|}
\hline Numb. & Category & Indicators & Parameters \\
\hline \multirow{2}{*}{1} & \multirow{2}{*}{ Maintenance } & frequency of maintenance & drainage cleaning frequency \\
\hline & & cost of maintenance & drainage cleaning cost per years \\
\hline \multirow{5}{*}{2} & \multirow{5}{*}{ Operational } & type of drainage & type of drainage \\
\hline & & \multirow[b]{2}{*}{ condition of drainage } & drainage physic condition \\
\hline & & & drainage height condition of road \\
\hline & & \multirow{2}{*}{ operation of drainage } & no water puddle on road \\
\hline & & & no water puddle on drainage \\
\hline \multirow[t]{2}{*}{3} & \multirow[t]{2}{*}{ Social } & $\begin{array}{l}\text { government response rate } \\
\text { of drainage problem }\end{array}$ & government response rate of drainage problem \\
\hline & & society awareness & society awareness rate of drainage \\
\hline \multirow{3}{*}{4} & \multirow{3}{*}{ Environment } & \multirow{2}{*}{ status of CSO } & water treatment facilty in roadway drainage system \\
\hline & & & $\begin{array}{c}\text { drainage development concerns on environment } \\
\text { aspect }\end{array}$ \\
\hline & & $\begin{array}{l}\text { Sustainability of drained } \\
\text { area }\end{array}$ & drainage development consider city spatial \\
\hline
\end{tabular}


KPIs hierarchy are also derived from expert consensus can be seen in Figure 1. Level 0 in the hierarchy is the goal of determining the priority KPI performance evaluation roads drainage Padang. Level 1 in the hierarchy is the category of IBC and level 2 in the hierarchy is the KPI that will be used in this study (Putri et al. 2012).

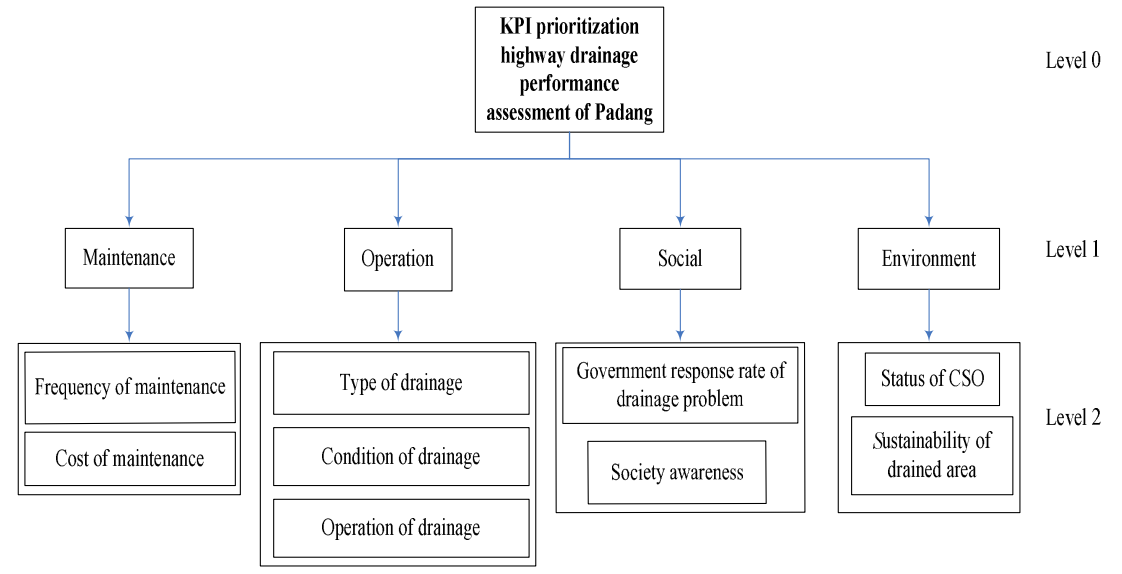

Figure 1. Hierarchy AHP Weighting

\subsection{KPI weighting}

Determination of weights using Expert Choice software that implements the method of Analytical Hierarchy Process (AHP).The weighting results obtained by weighting each category KPI, the local weight and global weight each KPI and value inconsistency ratio $<0.1$ for each KPI and KPI category. Global weights each KPI refers to the degree of importance of each KPI against roads drainage performance assessment of Padang. Local weights and global weight each KPI, KPI categories will be used in the calculation of the value of performance and level of performance. Value inconsistency ratio $<0.1$ indicates that the experts are consistent in giving weight to each KPI and KPI category. Value inconsistency ratio $<0.1$ also indicates that the weighting has been done correctly. KPI weighting results of roads drainage can be seen in Table 2 .

Table 2. AHP Weighting

\begin{tabular}{|c|c|c|c|c|c|c|c|}
\hline Criteria & $\begin{array}{c}\text { Criteria } \\
\text { Weight of } \\
\text { Goal }\end{array}$ & $\begin{array}{l}\text { Inconsistency } \\
\text { Ratio }\end{array}$ & Indicators & $\begin{array}{l}\text { Inconsistency } \\
\text { Ratio }\end{array}$ & $\begin{array}{l}\text { Global } \\
\text { Weigth }\end{array}$ & $\begin{array}{c}\text { Local } \\
\text { Weight }\end{array}$ & Summary \\
\hline \multirow{2}{*}{ Maintenance } & \multirow{2}{*}{0,205} & \multirow{8}{*}{0,02} & frequency of maintenance & \multirow{2}{*}{0} & 0,112 & 0,500 & \multirow{2}{*}{1} \\
\hline & & & cost of maintenance & & 0,112 & 0,500 & \\
\hline \multirow[b]{2}{*}{ Operation } & \multirow[b]{2}{*}{0,169} & & type of drainage & \multirow[b]{2}{*}{0,02} & 0,093 & 0,550 & \multirow[b]{2}{*}{1} \\
\hline & & & condition of drainage & & 0,040 & 0,240 & \\
\hline \multirow[t]{2}{*}{ Social } & \multirow[t]{2}{*}{0,288} & & $\begin{array}{l}\text { government response rate of drainage } \\
\text { problem }\end{array}$ & \multirow[t]{2}{*}{0} & 0,079 & 0,333 & \multirow[t]{2}{*}{1} \\
\hline & & & society awareness & & 0,158 & 0,667 & \\
\hline \multirow{2}{*}{ Environment } & \multirow{2}{*}{0,338} & & status of CSO & \multirow{2}{*}{0} & 0,185 & 0,500 & \multirow{2}{*}{1} \\
\hline & & & Sustainability of drained area & & 0,185 & 0,500 & \\
\hline
\end{tabular}

\subsection{Determination of Performance Standards Achievement}

Roads drainage performance assessment of Padang done by filling out performance evaluation by expert predetermined. Each rater assessed by looking at the actual performance of the roads drainage for the city of Padang is compared to the standard assessments predetermined. The performance target for all KPI is a scale of 5 while the lower limit is a 1 . Scale 5 shows the best performance road drainage and a 1 shows the worst performance of road drainage. Furthermore, to determine the value of each KPI is done using 
Objective Matrix, by the multiplication between the weight and the actual score obtained. Further processing of the data to the actual score of the input data by using a geometric mean expert and objective matrix. The level of achievement of the performance objectives set by the model matrix (OMAX). OMAX Model consists of 10 levels of achievement. The criteria for each level of performance are based on achievement of performance standards that have been defined previously.

\subsection{Performance Evaluation}

The results of the performance assessment of each expert will be entered into the Objective Matrix (OMAX) table. Assessment table contains actual scores given by 5 respondents for each KPI. Actual performance assessment scores given by each respondent is different. The difference in valuation is combined using the geometric mean. Merger can merge into one differing perceptions of the same value. This value will be included in the calculation table OMAX. OMAX table will show the results of the assessment and the level of achievement of the performance of the roads drainage Padang. Table OMAX roads drainage performance assessment of Padang can be seen in Table 3.

Table 3. Objective Matrix (OMAX) Assessment Table

\begin{tabular}{|c|c|c|c|c|c|c|c|c|c|c|}
\hline \multirow{3}{*}{ KPI } & \multicolumn{9}{|c|}{ " KPI Category } & \multirow{3}{*}{ Note } \\
\hline & \multicolumn{2}{|c|}{ Maintenance } & \multicolumn{3}{|c|}{ Operation } & \multicolumn{2}{|c|}{ Social } & \multicolumn{2}{|c|}{ Environment } & \\
\hline & A1 & A2 & B1 & B2 & B3 & $\mathbf{C 1}$ & $\mathrm{C2}$ & D1 & D2 & \\
\hline Achievement & 2,00 & 2,00 & 1,00 & 2,00 & 1,00 & 2,50 & 1,00 & 1,50 & 2,50 & \\
\hline 10 & 5,00 & 5,00 & 5,00 & 5,00 & 5,00 & 5,00 & 5,00 & 5,00 & 5,00 & Very Good \\
\hline 9 & 4,50 & 4,50 & 4,50 & 4,50 & 4,50 & 4,50 & 4,50 & 4,50 & 4,50 & \multirow{3}{*}{ Good } \\
\hline 8 & 4,00 & 4,00 & 4,00 & 4,00 & 4,00 & 4,00 & 4,00 & 4,00 & 4,00 & \\
\hline 7 & 3,50 & 3,50 & 3,50 & 3,50 & 3,50 & 3,50 & 3,50 & 3,50 & 3,50 & \\
\hline 6 & 3,00 & 3,00 & 3,00 & 3,00 & 3,00 & 3,00 & 3,00 & 3,00 & 3,00 & \multirow{2}{*}{ Moderate } \\
\hline 5 & 2,50 & 2,50 & 2,50 & 2,50 & 2,50 & 2,50 & 2,50 & 2,50 & 2,50 & \\
\hline 4 & 2,00 & 2,00 & 2,00 & 2,00 & 2,00 & 2,00 & 2,00 & 2,00 & 2,00 & \multirow{3}{*}{ Poor } \\
\hline 3 & 1,50 & 1,50 & 1,50 & 1,50 & 1,50 & 1,50 & 1,50 & 1,50 & 1,50 & \\
\hline 2 & 1,00 & 1,00 & 1,00 & 1,00 & 1,00 & 1,00 & 1,00 & 1,00 & 1,00 & \\
\hline 1 & 0,00 & 0,00 & 0,00 & 0,00 & 0,00 & 0,00 & 0,00 & 0,00 & 0,00 & Very Poor \\
\hline Actual Score & 4 & 4 & 2 & 4 & 2 & 5 & 2 & 3 & 5 & \multirow{3}{*}{$\begin{array}{c}\text { Total } \\
\text { Performance } \\
\text { Score }\end{array}$} \\
\hline Indicator Weight & 0,500 & 0,500 & 0,550 & 0,240 & 0,210 & 0,333 & 0,667 & 0,500 & 0,500 & \\
\hline $\begin{array}{c}\text { Value Performance } \\
\text { Indicators }\end{array}$ & 2,000 & 2,000 & 1,100 & 0,960 & 0,420 & 1,665 & 1,334 & 1,500 & 2,500 & \\
\hline Category Weight & \multicolumn{2}{|c|}{0,205} & \multicolumn{3}{|c|}{0,169} & \multicolumn{2}{|c|}{0,288} & \multicolumn{2}{|c|}{$\mathbf{0 , 3 3 8}$} & \multirow[b]{2}{*}{3,455} \\
\hline $\begin{array}{c}\text { Value Performance } \\
\text { Criteria }\end{array}$ & \multicolumn{2}{|c|}{$\mathbf{0 , 8 2 0}$} & \multicolumn{3}{|c|}{0,419} & \multicolumn{2}{|c|}{0,864} & \multicolumn{2}{|c|}{1,352} & \\
\hline
\end{tabular}

Roads drainage performance of Padang has a 3.455 level of achievement. Value of 3.455 is considered satisfactory performance bad. Score actual performance of each KPI will be compared to the scale of the achievement level predetermined. Comparison of actual performance against achievement levels for all indicators can be seen in Figure 2. 


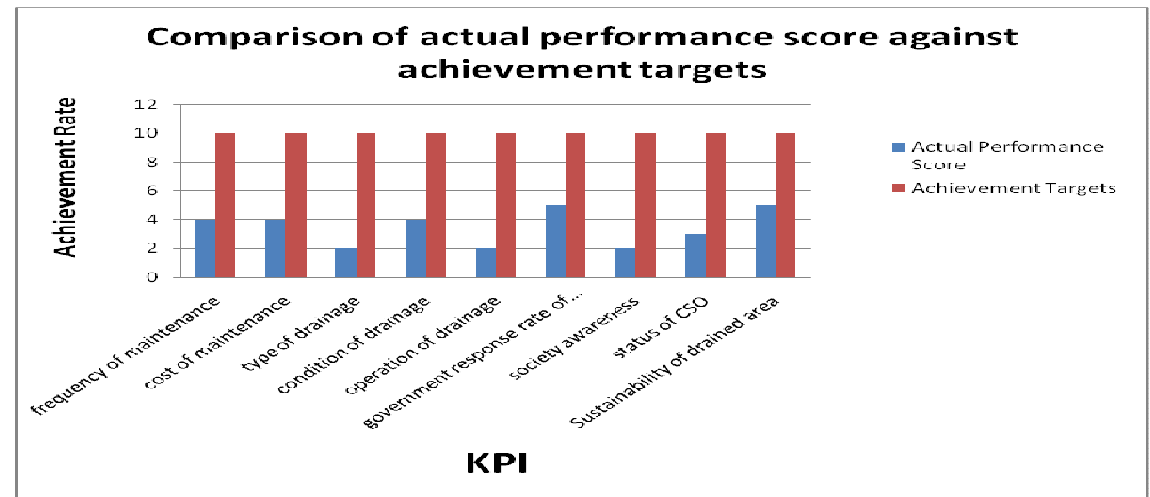

Figure 2. Comparison of actual perfromance score against achievement targets

\section{Conclusions}

1. Performance evaluation system designed to assess the performance could be a reliable drainage roads with roads drainage case study in the city of Padang.

2. Performance evaluation system designed to have 4 categories Key Performance Indicators (KPIs), namely Maintenance, Operational, Social, and Environment.

3. Performance evaluation system that is designed to have nine KPI parameters and performance measures for each KPI. 9 KPI is the frequency of maintenance, cost of maintenance, type of drainage, drainage, drainage operations, and the government's response to the problems of drainage, public awareness, waste status and sustainability of the drainage basin.

4. Actual performance level in the city of Padang roads drainage in general at the present time is 3.455 out of 10. This performance level is at the level of bad. This happens because of faulty drainage, high sediment; lack of public awareness, government response was slow, and so forth. Evaluation of performance assessment and performance improvement of drainage is the responsibility of the government.

5. Roads drainage actual performance of Padang City in particular seen from the performance level of each KPI, the KPI frequency of maintenance (poor achievement levels), KPI maintenance costs (poor achievement levels), KPI type drainage (poor achievement levels), KPI drainage (poor achievement levels), operating KPI drainage (poor achievement levels), KPI level of the government's response to the problems of drainage (medium level of achievement), KPI awareness (achievement level 2), KPI status of waste (poor achievement levels), and regional sustainability KPI drainage flow (moderate level of achievement). Performance level in each different KPIs but most every KPI performance level at the level of bad.

\section{REFERENCES}

Kamil, Insannul, et al. (2012). Analysis of Factors Influencing Awareness of Road Maintenance as Public Asset Using Analytical Hierarchy Process (Case Study: Padang City Indonesia). International Conference on Asset and Facility Management. Padang Indonesia.

Kamil, Insannul, Alias, Buang and Hakim, Mohammed. (2012). Developing Model of Infrastructure Asset Maintenance in Developing Countries Using Fuzzy Screening System-AHP Approach (Case Study: Main Roads in Padang City, Indonesia). International Real Estate Conference. Kuala Lumpur. Malaysia.

Kamil, Insannul, et al. (2012). Designing Model of Database and GIS Application for Road Performance Management. 4th International Conference on Geo-information Technology for Natural Disaster management. Colombo. Sri Lanka. 
Kamil, Insannul, et al. (2012). Computer Assisted Life Cycle Costing of Road Assets for Disaster Zone in Padang Indonesia. International Conference on Construction Industry, Facilities and Asset Management. Padang. Indonesia.

Kamil, Insannul, et al. (2012). Life Cycle Costing of Road Assets for Disaster Zone (Case: Alai-By Pass Roads, Padang Indonesia). International Conference on Construction Industry, Facilities and Asset Management. Padang. Indonesia.

Kamil, Insannul, et al. (2012). Development of Model of Policy for City Road Infrastructure Network Maintenance System Using Critical Success Factors (Case Study: Padang City Indonesia. Conference of ASEAN Federation of Engineering Organizations. Phnom Penh. Cambodia.

Nurhudayah. Studi Genangan Air Terhadap Kerusakan Jalan di Kota Gorontalo. (2009). Simposium XII FSTPT. Universitas Kristen Petra Surabaya. Gorontalo. Indonesia

Law of The Republic of Indonesia. Number 38 (2004). Jakarta. Indonesia

Putri, Nilda Tri, Kamil, Insannul, dan Kalani, Cresti. (2012) "Perancangan Sistem Penilaian Kinerja Fasilitas Publik Menggunakan Key Performance Indicators (Studi Kasus Sistem Drainase Kota Padang)", $1^{\text {st }}$ Technology, Industry, Enterpreneurships Conference, hal. $149-154$, ISSN 2302-478X, 18 Oktober 2012. 